\title{
KOSTEL SV. VÁCLAVA V ŽABONOSECH (OKRES KOLÍN) A JEHO POČÁTKY
}

\author{
SOŇA HENDRYCHOVÁ - JAN FROLÍK
}

Abstrakt: Článek shrnuje poznatky ze záchranného archeologického výzkumu v letech 2009 až 2010, který zjistil předrománskou jednolodní stavbu, prestavěnou posléze v trojlodni baziliku. Následovala novostavba jednolodního románského kostela s dodatečně vloženou tribunou a pristavěnou věži. Prozkoumáno bylo celkem 91 hrobů, z nichž nejméně tři náleží předrománské stavebni fázi a nejméně 28 k románské stavebni etapě.

Klíčová slova: románská architektura - kostel - bazilika - pohřebiště.

\section{The Church of St. Wenceslas in Žabonosy (Kolín District) and its Origins}

Abstract: This paper sums up information from rescue archaeological research in 2009-2010 that disclosed a single-nave pre-Romanesque construction later converted into a triple-nave basilica. It was followed by the construction of a single-nave Romanesque church with a gallery added later and a tower. 91 graves were investigated, at least three of which belong in the pre-Romanesque building phase and at least 28 in the Romanesque building phase.

Key words: Romanesque architecture - church - basilica - burial ground.

\section{1. Úvod}

Kostel sv. Václava v Žabonosech (okr. Kolín) je nenápadnou, ale významnou památkou románského i gotického stavitelství (obr. 1). V odborné literatuře je považován za velmi starobylou stavbu s poukazem na nález zdiva v roce 1937 v západní části kostela (Budaváry 1939; 1939a; Merhautová 1971, 367-368; Turek 1963; Sommer-Vaněk 2007, 27-28). Tento nález však nebyl nikdy odborně vyhodnocen a jeho stáŕí a interpretace vzbuzovaly pochybnosti. Proto byl v rámci opravy zdevastovaného kostela uplatněn požadavek na záchranný archeologický výzkum, který by pomohl ozřejmit některé nejasnosti v minulosti kostelní stavby. Navíc bylo zřejmé, že rekonstrukční práce značně poznamenají původní terény kolem kostela a zanikne množství informací a nálezů spojených s minulostí této pozoruhodné stavby.

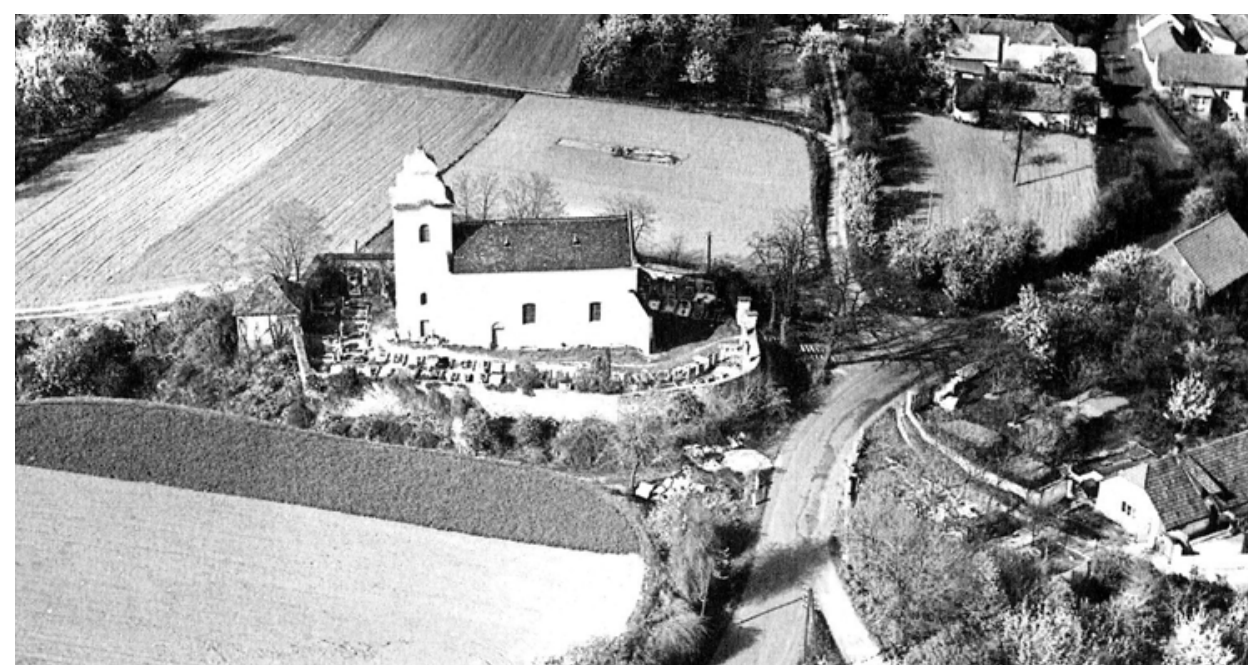

Obr. 1. Žabonosy, kostel sv. Václava. Celkový pohled. Podle Sedláček-Vencl 1974.

Abb. 1. Žabonosy, St. Wenzelkirche. Gesamtansicht. Nach Sedláček-Vencl 1974. 
Záchranný archeologický výzkum byl zahájen v červnu a červenci 2009 zjištovací sondáží, která ověřila a potvrdila existenci raně a vrcholně stř̌edověkých situací vně (sondy 1-3) i v interiéru (sonda 4) kostela (Frolík 2009). Podle výsledků sondáže byl také upraven projekt rekonstrukce.

Druhá etapa archeologického výzkumu se odehrála v trase odvlhčovacího kanálu podél vnitřního i vnějšího líce celé stavby. Archeologicky byl hlouben kanál v celém průběhu v interiéru (sondy 12-15, 27-28), v exteriéru jen podél románské části kostela (sondy 11, 16-26). V gotické části bylo zjištěno, že při dřivějších opravách kostela (v r. 1937 nebo dříve?) byly úseky základového zdiva podezděny a výkop pro podezdívání zničil archeologické terény až do úrovně podloží. Druhá etapa výzkumu proběhla s několika přestávkami v období srpna 2009 až dubna 2010 (Frolík 2010; 2010a).

\section{Historie stavby a dějiny bádání}

Dosavadní literatura uvažuje o vzniku kostela již koncem 10. století. V roce 1937 byl v interiéru proveden místním děkanem výkop, který zjistil, že sloupek empory stojí na starším zdivu, interpretovaném jako pozůstatek apsidy (Budaváry 1939; 1939a). Bez zřejmých souvislostí bylo toto zdivo datováno do 10. století a spojováno s aktivitami Slavníkovců (Turek 1963; 1982). Podle této hypotézy byl na místě původního kostela ve 12. století nebo v první čtvrtině 13 . století postaven v románském slohu kostel nový. V první polovině 14. století byl prodloužen k východu (nová lod' a pravoúhlý presbytář). Sakristie v podobě boční kaple byla doplněna koncem 14. století a uvažuje se o vazbě na hut' Petra Parléře. Barokní úpravy jsou datovány k roku 1721 (Poche a kol. 1982, 383-384). Stavební vývoj doplňuje zmínka o přestavbě roku 1600, event. 1609 (Merhautová 1971, 367). Datování románské části stojící stavby kolísá mezi 12. stoletím, dobou kolem roku 1260 nebo koncem první třetiny 13. století. Sama A. Merhautová (1971,367-368) stavbu datuje do prvé čtvrtiny 13. století. Postupně chátrající stavba a opadávání omítek dovolily upřesnit stavební vývoj kostela, především byla do doby románské zařazena také věž (Sommer 1993; Varhaník 1997). Písemné zprávy z období výstavby románské stavby se nedochovaly. Nejstarší zmínka o kostelu jako farním je k roku 1352, roku 1357 jsou zmíněni Bohunek a Petr ze Žabonos jako patroni zdejšího kostela (,,de Zabonos ad eccl.“ - Profous-Svoboda 1957). Ve vsi stávala tvrz (Sedláček 1998, 1025; Tůma 1915). Žabonosy vystř́idaly četné majitele. Po Bohunkovi a Petrovi ze Žabonos ves drželi páni z Jenštejna, po nich Mikuláš Pýšek z Hradenína. Dále do roku 1547 vlastnilo Žabonosy město Kouřim. Roku 1547 král Ferdinand I. zabavil kouřimským Žabonosy spolu s Toušicemi, Krychnovem a Bošicemi. Zabavené zboží odkoupil Kryštof Skuhrovský ze Skuhrova a na Popovicích. Dále držel ves rod Horňateckých z Dobročovic. Od roku 1635 vlastnili Žabonosy Winckelhoferové. Dne 12. června 1652 byla ves odprodána Regině Kateřině Bertholdové z Uherčic, čímž Žabonosy zůstaly nadále spojeny s radimským panstvím (Tůma 1915, 49-51).

Archeologicky jsou Žabonosy sledovány již od 19. století, ale převážná část získaných nálezů pochází z pravěku, zejména z neolitu, eneolitu, doby bronzové a doby laténské (Dvořák 1936, 153; NZ Žabonosy 1950; 1950a; 1950b; 1950c; 1950d; 1950e; 1950f; 1950g). Tři žárové hroby z pozdní doby bronzové byly objeveny J. Budavárym přímo uvnitř kostela sv. Václava (Budaváry 1939a). V roce 1893 prokopal J. Waněk pohřebiště čítající více než 100 hrobů. Pohřebiště se nacházelo východně od kostela na druhé straně silnice spojující Žabonosy a Přebozy (Píč 1909, 388; Kudrnáč 1963, 189-190). Hroby byly „těsně podle sebe kladené“ (Píč 1893, 437-438), kostry ležely na zádech se západovýchodní orientací a doprovázely je pouze „nemnohé milodary“. Bylo objeveno pouze několik nálezů - tři esovité záušnice, tři kroužky, z nichž dva „, esovitým zakončením na obou koncich“, čtyři kroužky s esovitým ukončením, ,jež na rukou jako náramky nošeny byly“, bronzový prsten s kulatým hladkým štítkem, bronzový proužek a zlomky železa, o nichž se nálezci domnívali, že by mohly pocházet z ostruhy (Píč 1893, 437-438). J. L. Píč datoval pohřebiště ,podle zř́lka vyskytujícich se milodarü“ přibližně „do 12. věku“ $(1893,438)$.

Kostel byl postaven na nevýrazném výběžku terénu. Ze strany severní je vydělen nepř́iliš převýšenou hranou, na straně jižní se nachází odpadem postupně vyplňovaný zářez. K západu postupně vykliňuje a spíše než o pozůstatek př́kopu jde o torzo úvozu. Původní terén na výběžku 
se skláněl k východu. Románská část kostela je postavena na rovném terénu na terénní hraně, část gotická již ve svahu pod ní. Podložím lokality je spraš, na kterou nasedá tmavohnědá sprašová hlína (původní půdní horizont).

Mylné jsou údaje o existenci (slavníkovského) hradiště, obehnaného příkopem a valem, v jehož areálu má kostel stát (Píč 1896, 437; 1909, 351-352, 365, 387-388), přestože se tato informace houževnatě udržuje v literatuře (Sommer-Vaněk 2007, 27). Existující terénní konfigurace takovou interpretaci nedovoluje. Údajný val není dnes nikde patrný (což nemusí nic znamenat). Ostatně Z. Sedláček a S. Vencl (1974) již v roce 1974 opatrně konstatovali, že po valu a př́ikopu „nezůstaly v terénu výraznějši stopy“. Kdybychom uvažovali obvyklou šíri těchto konstrukcí nebo použili analogii, na kterou se často odkazuje (nedaleké Vrbčany, okr. Kolín), nezbyla by na ploše dnešního hřbitova kromě kostela téměř žádná plocha. Povrchové průzkumy v okolí kostela přinesly zlomky keramiky ,pozdně hradištního charakteru“ a vzhůru vytažené okraje (Princ-Hejna-Richter-Smetánka 1965; Sedláček-Vencl 1974), event. zlomky pravěké a blíže necharakterizované stř̌edověké (Tvrdík 2005; 2005a).

První průzkum v interiéru kostela proběhl v roce 1937. Výkopy v kostele začal kanovník K. Koděra, jehož činnost sledoval MUDr. František Dvořák. V dopise z 10. června 1937 (Dvořák 1937) zpravuje o celé akci Archeologický ústav. V interiéru kostela byla tehdy odkryta patka sloupu podpírajícího emporu, $\mathrm{v}$ tomto místě $\mathrm{v}$ hloubce $60 \mathrm{~cm}$ se ukázalo starší zdivo půlkruhovitého půdorysu (obr. 2). Před hlavním oltářem byly nalezeny kostrové pohřby. Byl objeven také vchod do cihlové hrobky s rakvemi. F. Dvořák další kopání K. Koděrovi nedoporučil a obrátil se dopisem na Archeologický ústav. Na jeho podnět s výzkumem pokračoval V. Budaváry.

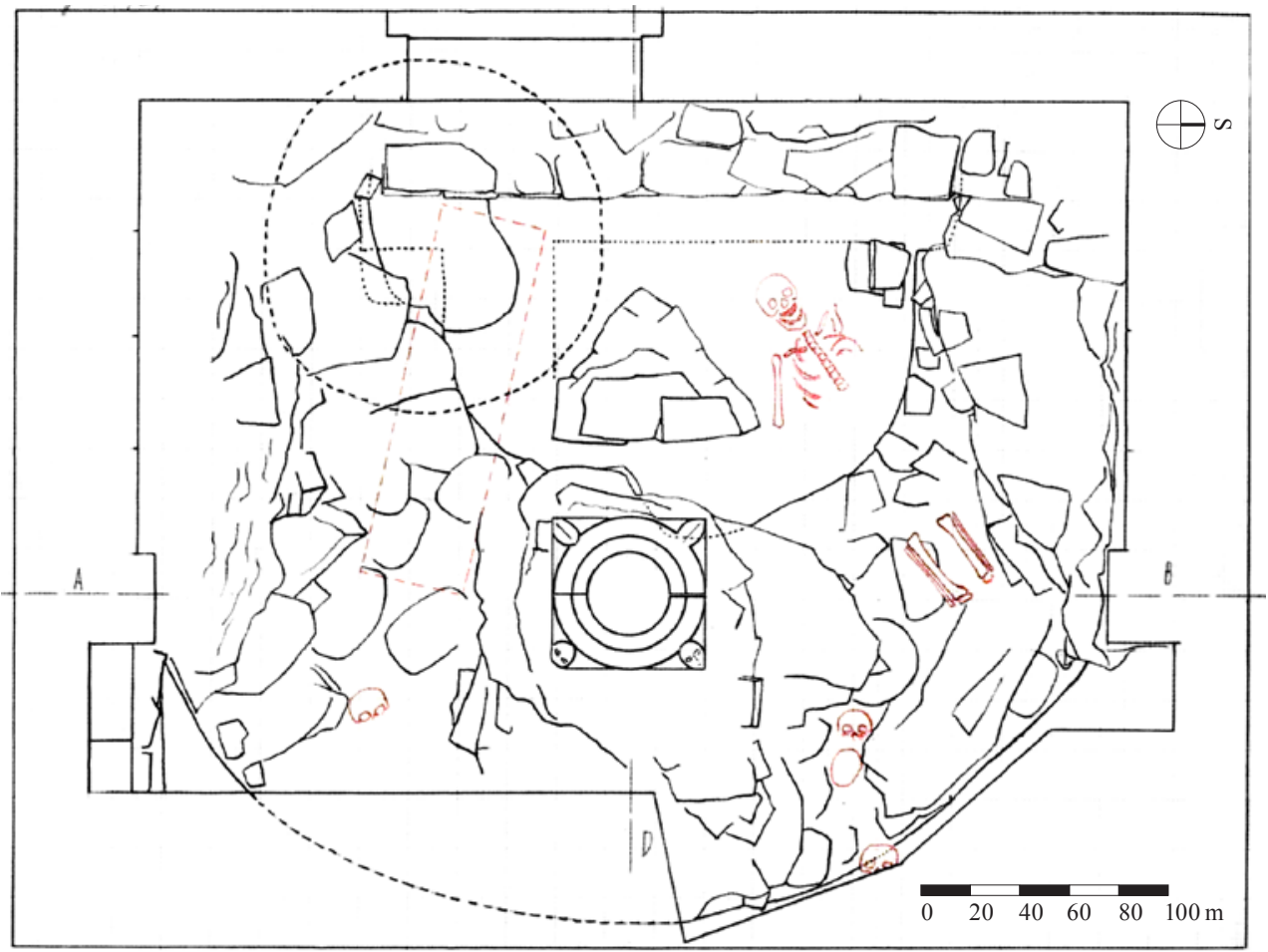

Obr. 2. Žabonosy, kostel sv. Václava. Terénní dokumentace odkryvu apsidy předrománské stavby z roku 1937. Kresba V. Budaváry. Archiv ARÚ AV ČR, Praha, v. v. i.. č. j. 896/39.

Abb. 2. Žabonosy, St. Wenzelkirche. Geländedokumentation von der Freilegung der Apsis des vorromanischen Baus aus dem Jahr 1397. Zeichnung V. Budaváry. Archiv des Archäologischen Instituts der Akademie der Wissenschaften der Tschechischen Republik, AZ 896/39. 
Z jeho výzkumu se dochovaly zprávy (Budaváry 1939; 1939a) s dostatečnou kresebnou i fotografickou dokumentací. Je z nich patrné, že V. Budaváry pokračoval s výzkumem odkryté situace pod tribunou a především celou situaci náležitě dokumentoval. Je zjevné, že kopal také na hřbitově, kde odkryl několik dalších hrobů, ale tyto výkopy nedovedeme přesně lokalizovat. Další akce kontrolovaná archeology proběhla až v roce 1994. Výkop pro přípojku elektrického proudu ke kostelu byl negativní (Sedláček 1994).

\section{Stavební vývoj kostela}

Záchranný archeologický výzkum podstatně doplnil naše znalosti o počátcích a stavebním vývoji kostela a dovoluje korigovat některé hypotézy. Kostel byl založen na neosídleném místě. Nebyly zjištěny pozůstatky starších sídlištních či pohřebních aktivit a ani sídlištní aktivity současné s některou fází kostela. Na východní straně výkopy pro kanalizaci protnuly i okrajovou část hřbitova a pokračovaly vně hřbitovní zdi. Ve výkopu nebyly zachyceny žádné pozůstatky opevnění (valu) předpokládaného hradiště.

Nejstarší církevní stavbě skutečně náleží apsida situovaná pod tribunou v západní části lodi, odhalená poprvé již v roce 1937. Dochovaná šířka základového zdiva se pohybuje mezi 1,35 a 1,6 m. Obloukovitě probíhající zdivo lze interpretovat pouze jako apsidu o dochované (neúplné) šířce $4 \mathrm{~m}$ a dochované vnitřní světlosti $2,3 \mathrm{~m}$. V apsidě byl zdokumentován zbytek základu oltáře. $\mathrm{Na}$ apsidu navazovala zřejmě obdélná lod', z níž známe úseky negativů bočních zdiv. Negativy jsou široké 1,2 až $1,3 \mathrm{~m}$ při celkové šířce lodi $5 \mathrm{~m}$ a vnitřním prostoru širokém 2,5 m (obr. 3:A). Zjištěno nebylo západní ukončení, které se pravděpodobně nachází pod skupinou novodobých hrobek mezi stojícím kostelem a márnicí. Délka kostela činí i s apsidou minimálně $9,5 \mathrm{~m}, \mathrm{z}$ toho na lod' připadá asi $7 \mathrm{~m}$. Maltě z této prvé etapy kostela odpovídá ještě pojivo v krátkém úseku zdi ( 0,7 m s odhaleným jižním lícem), jejíž převážná část je překryta jižní zdí lodi stojícího kostela. Snad šlo o jakousi přístavbu situovanou u nároží jihovýchodního nároží lodi a apsidy kostela.

Další stavební etapu tvoří dvě apsidy, odhalené vně na severní a jižní straně lodi. Apsidy byly odkryty v podobě základového zdiva o šíři $1,3 \mathrm{~m}$ v ploše sond 26 a 29. Na zdivo hlavní lodi byly napojeny s využitím výrazného ústupku. Jejich pokračování (vnější strana) a navazující zdiva bočních lodí zůstávají skryta v nezkoumaném terénu. Apsidy lze rekonstruovat jako $4 \mathrm{~m}$ široké (vnitřní prostor $1,2 \mathrm{~m}$ ). Pokud bylo napojení na stěny bočních lodí provedeno také pomocí ústupku, vycházela by šíŕka bočních lodí na $4 \mathrm{~m}$ (vnitřní prostor $2,7 \mathrm{~m}$ ). Na základě nalezených fragmentů můžeme podobu druhé etapy stavby rekonstruovat jako malou trojlodní baziliku (obr. 3:B). Lze rekonstruovat její celkovou šiřku (12,5 m) a východní závěr. Délka zůstává stejná jako u předchozí etapy (minimálně $9,5 \mathrm{~m}$ ) s tím, že ani pro druhou etapu neznáme její západní zakončení. Rozdělení stavby na dvě etapy vyplývá ze studia maltového pojiva, které se u hlavní lodi a hlavní apsidy odlišuje od malt v obou bočních apsidách. Obtížné je datování obou etap stavby, protože odkrytá situace neposkytla vhodné nálezy. Dochovalo se pouze základové zdivo bez architektonických článků. Kromě části základu oltáře neznáme ani vnitřní vybavení stavby. Jednoznačné je pouze překrytí zdivy románské fáze kostela. Na základě stratigrafických pozorování můžeme spojit $\mathrm{s}$ touto stavbou tři hroby, $\mathrm{v}$ nichž však nebyla nalezena hrobová výbava. Předběžně můžeme objevenou stavbu datovat do staršího 12. či 11. století. Její funkce a význam pro místní osídlení je úkolem dalšího zkoumání.

V průběhu 12. století nebo v první čtvrtině 13. století (Merhautová 1971, 367-368) byla na místě starší stavby postavena novostavba posunutá východním směrem. Šlo o jednolodní stavbu ukončenou na východní straně nedochovaným způsobem (nejpravděpodobněji však apsidou). Dochované torzo lodi má délku 5,3 m při šířce $6,2 \mathrm{~m}$ (vnitřní prostor $4 \mathrm{~m}$ ). K vnější straně západní zdi byl připojen blok o rozměrech $2 \times 1,2$ m nejasného účelu (obr. 3:C). Nový kostel byl prrístupný dochovaným portálem z jižní strany. Původní úroveň podlahy a ani jiné části vnitřního vybavení se nedochovaly. 

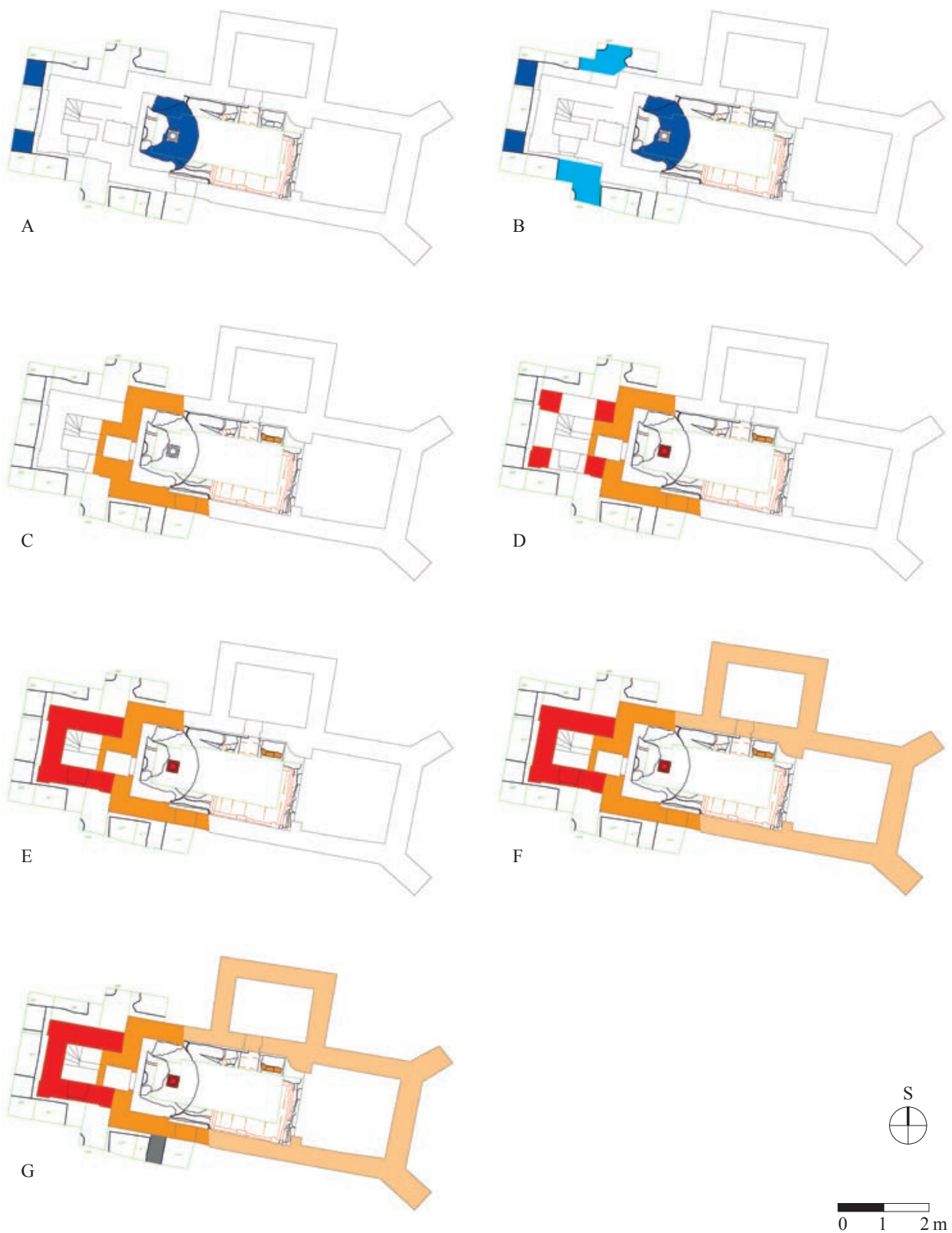

Obr. 3. Žabonosy, kostel sv. Václava. Vývojové fáze stavby odhalené archeologickým výzkumem. A - jednolodní kostel, 11. (?) století; B - trojlodní bazilika, 11.-12. století; C - jednolodní románský kostel, 12. století; D - jednolodní románský kostel s vloženou tribunou a přistavěnou věží s arkádou v přízemí, 12.-13. století; E - jednolodní románský kostel, arkády v přízemí věže zazděny, 12.-13. století; F - gotická přestavba s presbytářem o stejné šíři jako lod' a sakristií, 14. století; G - připojení předsíně k jižní straně kostela, kolem roku 1600 (?). Na základě podkladu firmy Geo.cz vypracoval J. Frolík. Abb. 3. Žabonosy, St. Wenzelkirche. Entwicklungsphase des durch die archäologische Grabung freigelegten Baus. A - einschiffige Kirche, 11. (?) Jhdt.; B - dreischiffige Basilika, 11.-12. Jhdt.; C - einschiffige romanische Kirche, 12. Jhdt.; D - einschiffige romanische Kirche mit eingefügter Tribüne und angebautem Turm mit Arkade im Erdgeschoss, 12.-13. Jhdt.; E - einschiffige romanische Kirche, zugemauerte Arkaden im Erdgeschoss des Turms, 12.-13. Jhdt.; F - gotischer Umbau mit Chorraum von gleicher Breite wie Schiff und Sakristei, 14. Jhdt.; G - Anschluss des Vorraums an die Südseite der Kirche, um 1600 (?). Anhand der Unterlagen der Firma Geo.cz ausgearbeitet von J. Frolík. 
V dalším vývoji byl kostel dále upravován v románském stavebním stylu. Byl vybaven tribunou nesenou tordovaným sloupkem s ozdobnou patkou a hlavicí. Úroveň podlahy, s níž počítá tento sloupek, je níže, než je koruna základu okolního románského zdiva. Musí tedy jít o dodatečnou úpravu. Podle dochované spáry byla dodatečně připojena také věž o rozměrech $4 \times 4 \mathrm{~m}, \mathrm{v}$ jejímž interiéru se ocitl výše zmíněný blok zdiva (obr. 3:D). Spodní část zdiva věže nasvědčuje ještě dalším úpravám v románském stavebním stylu. Původně se její přízemí otevíralo do okolí arkádou o šíři 2,4 m. Arkáda byla dodatečně zazděna kvádříkovým zdivem (obr. 3:E, 4). Celkově můžeme uvažovat o dvou až třech stavebních románských (mikro)fázích.

Gotickou stavební etapu představuje prodloužení lodi kostela východním směrem a výstavba nového presbytáře o stejné šíri, jakou má lod' kostela. Presbytář byl na nárožích zpevněn opěráky. Zanikla tím východní část románského jednolodního kostela. Kostel tak získal délku $17 \mathrm{~m}$. Na rozdíl od dosavadních předpokladů byla ve stejné stavební etapě postavena i sakristie (obr. 3:F). Svědčí o tom provázání zdiv v základové úrovni. Zdiva gotické stavební fáze byla zahloubena poměrně

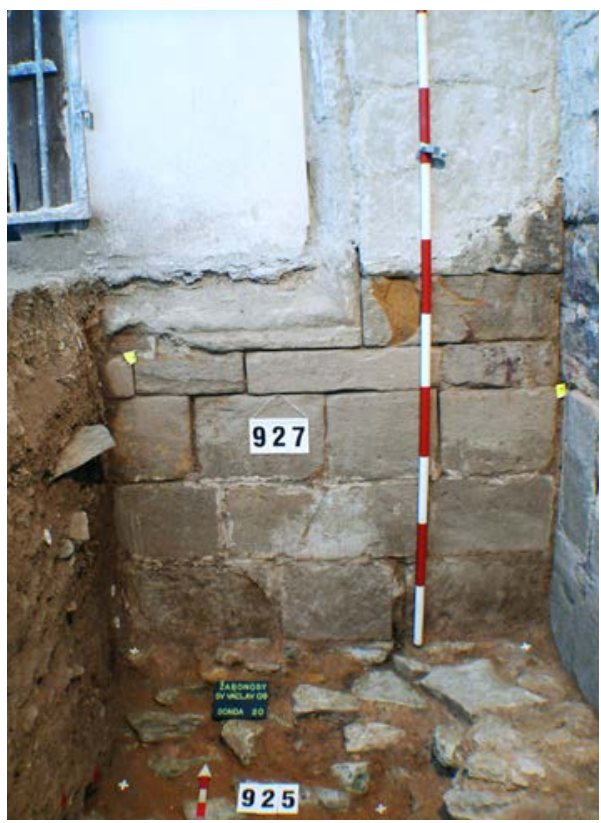

Obr. 4. Žabonosy, kostel sv. Václava. Jižní stana románské věže, sonda 21. Zdivo věže (927) s patrnou spodní částí východního ostění a prahu arkády. Foto P. Pinc.

Abb. 4. Žabonosy, St. Wenzelkirche. Südseite des romanischen Turms, Sondierschnitt 21. Turmmauerwerk (927) mit sichtbarem unteren Teil des östlichen Gewändes und Arkadenschwelle. Foto P. Pinc. mělce (např. na jižní straně pouze ca $0,6 \mathrm{~m}$ od současné úrovně terénu). Posun větší části kostela východním směrem (tj. po svahu dolů) a mělké založení bylo zřejmě př́ičinou statických problémů v pozdějším období. Pravděpodobně v gotické stavební etapě byla v jihozápadním rohu lodi kostela vyhloubena zásobní jáma lahvovitého průřezu, sloužící podle obdobných analogií jako úkryt na cenné předměty. Původní nálezový obsah se nedochoval, jáma byla vybrána a znovu zasypána během výkopových prací v roce 1937.

Další stavební úpravy kostela souvisí s vložením krypty do lodi kostela a do sakristie. Obě krypty byly spojeny chodbičkou. Vstup do obou krypt byl ze sakristie. Výstavba krypt zlikvidovala všechny starší podlahové úrovně v lodi kostela. Obě krypty byly založeny hluboko pod základovou spáru. Zejména $v$ lodi kostela to mohlo přispět ke statickým problémům. Krypty překrývala (v úplnosti v sakristii, fragmentárně v lodi kostela) dlažba z keramických dlaždic. Nejpravděpodobněji pochází ze stejné stavební etapy. Snad s úpravami kolem roku 1600 souvisí připojení předsíně před vchod do kostela (obr. 3:G). Barokní stavební úpravy se v interiéru kostela v archeologickém kontextu neprojevily, pokud bychom s nimi nespojovali dlažbu z keramických dlaždic.

Nejmladší stavební úpravy jsou spojeny s podezděním základů gotické stavební etapy na jižní a východní straně kostela. Tyto úpravy odstranily v šíři ca $1 \mathrm{~m}$ starší archeologické terény. Podél románské části kostela, zejména na západní straně věže se uložila vrstva stavebního odpadu. Ve stejné stavební etapě vznikl sokl z pískovcových desek, původně považovaný za středověký. V interiéru kostela spojujeme se stejnou úpravou výkopy v západní části lodi z roku 1937, dodatečně archeologicky dokumentované (Budaváry 1939). Během těchto výkopových prací byly také otevřeny krypty a jejich obsah rozchvácen, jak doložil průzkum mikrokamerou. V lodi byla odstraněna původní podlaha z keramických dlaždic. Položena byla podlaha nová (kamenné čtvercové dlaždice). Statické problémy tehdejší podezdění nevyřešilo. Další etapu jejich řešení představuje betonové zpevnění základů jihovýchodního nárožního opěráku provedené v nezjištěné době. 


\section{Pohřebiště}

Kolem kostela docházelo k intenzivnímu pohřbívání. Narušováním starších hrobů došlo k vytvoření až dvoumetrové hřbitovní vrstvy s nálezy z 11. až 19. století. V některých sondách bylo možné rozpoznat její starší (uloženina 309) a mladší horizont (uloženina 304). Předběžně lze soudit, že starší uloženina souvisí s románskou etapou existence kostela, mladší s gotickou a následujícími etapami. Celkem bylo odkryto 91 hrobů a jejich fragmentů (obr. 5). V interiéru kostela, v ploše neporušené stavbou krypty, bylo odkryto 11 hrobů (H3, 4, 6-8, 10, 17, 18, 20, 23 a 24), v sakristii fragmenty tří hrobů (H33-35), vně kostela pak 77 hrobů (H5, 9, 11-15, 19, $21,25-32$ a $36-91)$.

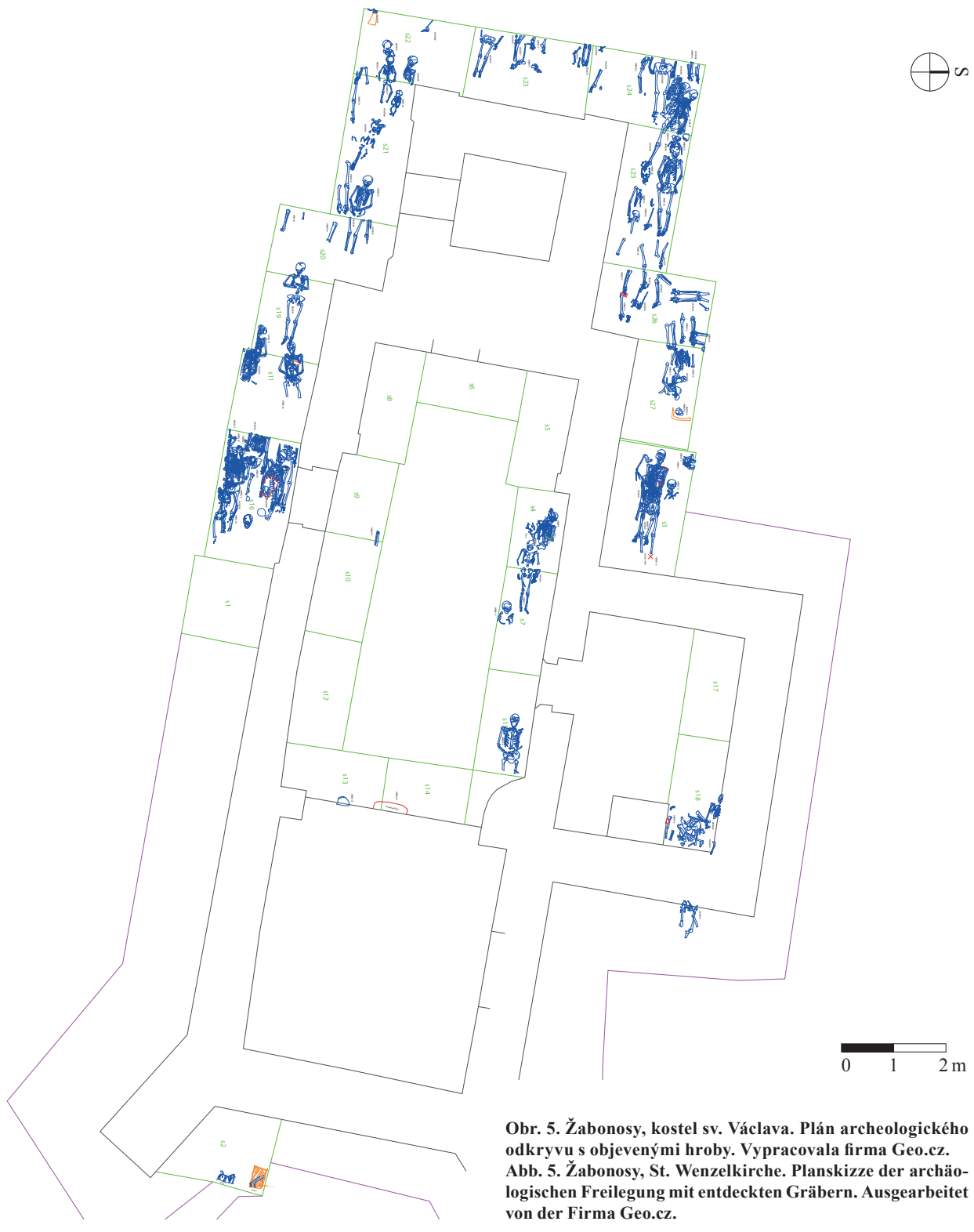




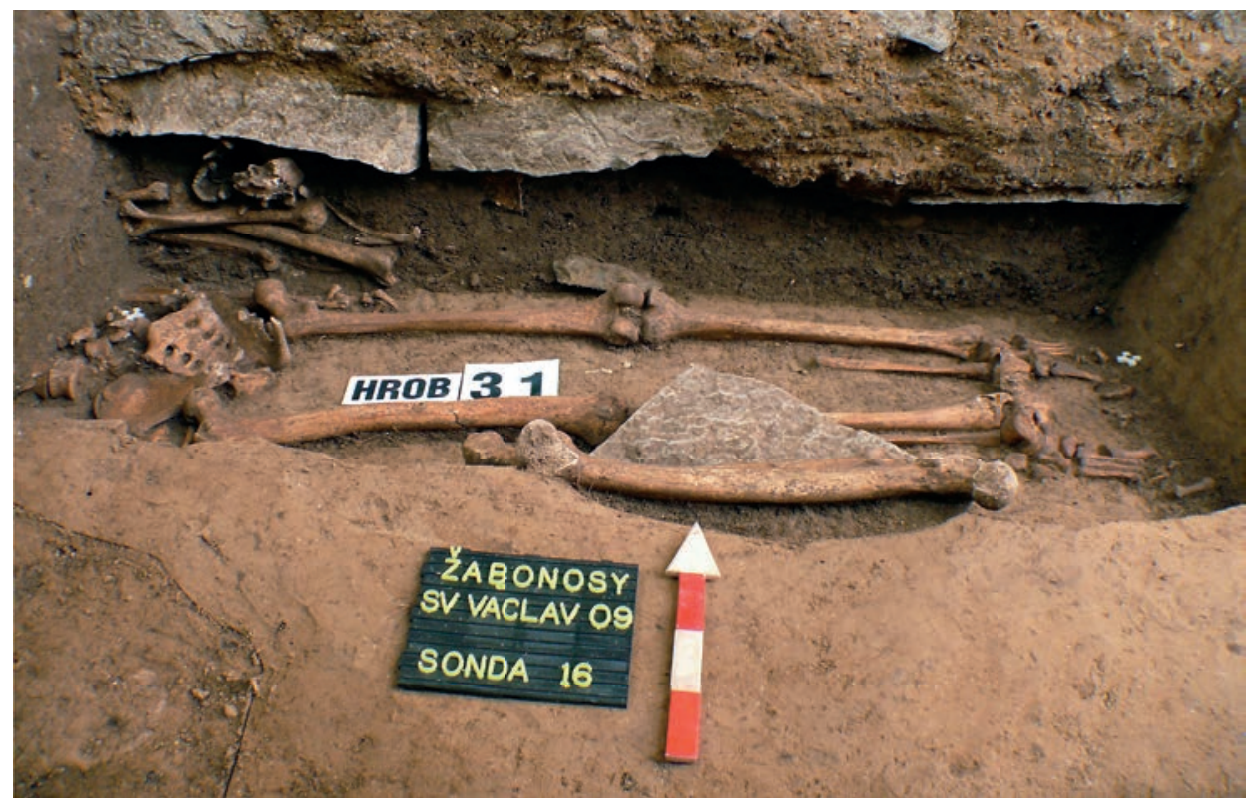

Obr. 6. Žabonosy, kostel sv. Václava. Hrob 31, překrytý zčásti zdivem jednolodního románského kostela z 12. století. Pod románským základem kostela patrny kosti staršího hrobu shrnuté k okraji hrobové jámy. Západní část hrobu porušena zdivem renesanční (?) předsíně. Foto P. Pinc.

Abb. 6. Žabonosy, St. Wenzelkirche. Teilweise vom Mauerwerk der einschiffigen romanischen Kirche aus dem 12. Jhdt. verdecktes Grab Nr. 31. Unter dem romanischen Fundament der Kirche am Rand der Grabgrube zusammengescharrtes Skelett eines älteren Grabes. Vom Mauerwerk des renaissancezeitlichen (?) Vorraums gestörter westlicher Teil des Grabes. Foto P. Pinc.

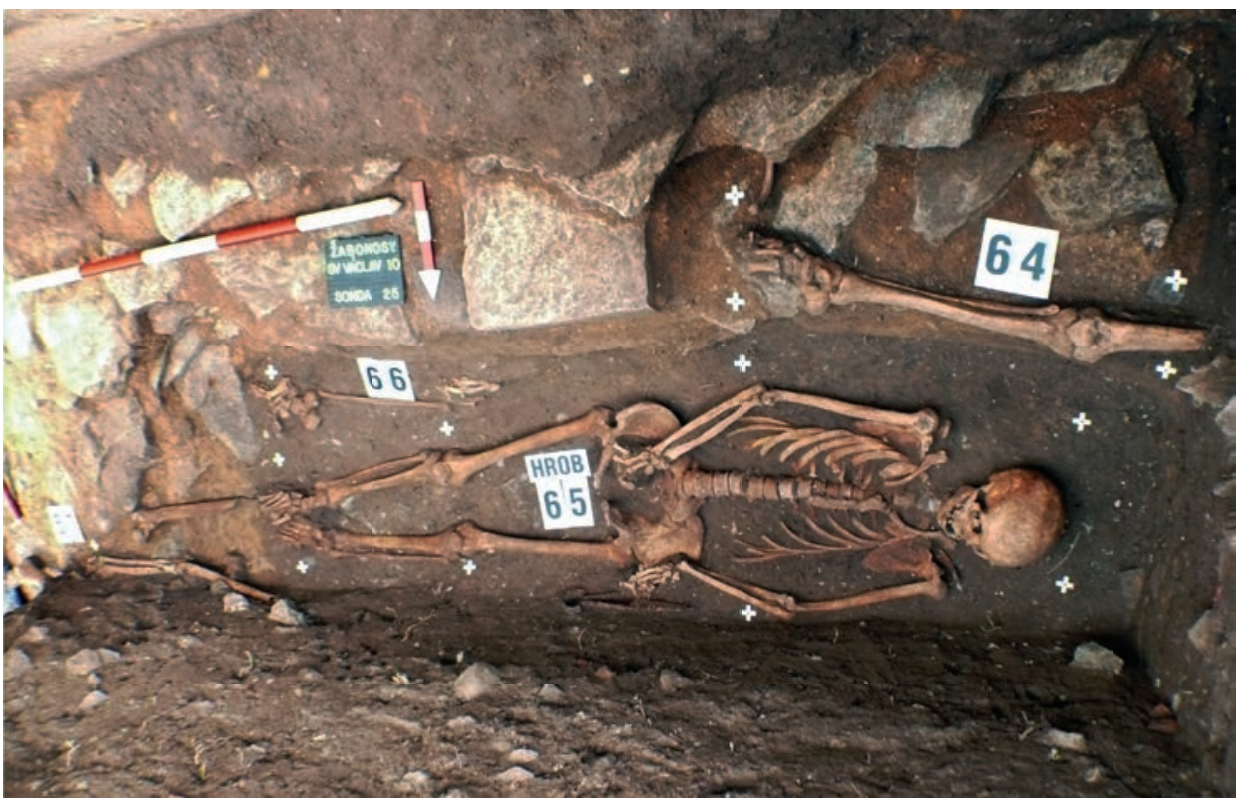

Obr. 7. Žabonosy, kostel sv. Václava. Hrob 65, jako milodar přiloženy ovčácké nůžky. Foto P. Pinc. Abb. 7. Žabonosy, St. Wenzelkirche. Grab 65, Schermesser als Grabbeigabe. Foto P. Pinc. 
Na základě stratigrafických vztahů a vztahů $\mathrm{k}$ jednotlivým stavebním fázím kostela bylo možno vyčlenit nejstarší hroby. Tři prokazatelně patřily již k předrománské fázi kostela (H31, 90 a pozůstatek hrobové jámy 1903). Hrob 31 je narušen základovým zdivem románské lodi (zdivo 903) a zároveň zdivem předsíně, která je mladší než gotická (zdivo 917 - obr. 6). Hrob 90 leží pod předrománskou prrístavbou severní lodi bazilikální stavby (zdivo 929), je tedy zjevné, že patří k první fázi, tj. k jednolodní kostelní stavbě. Pozůstatek hrobové jámy s výplní 1903 je stejně jako hrob 31 porušen základy románské lodi (zdivo 903).

Dalších nejméně 28 hrobů náleželo k románské stavbě. Nevelkou, ale významnou skupinu hrobů představují pohřby související se zdivem severní lodi bazilikální stavby (zdivo 929). Na této zdi leží superpozice hrobů 63 až 66, z nichž hrob 65 je nejmladší (obr. 7). Hroby tedy byly vyhloubeny po zániku bazilikálního kostela. Při kostře z hrobu 65 se podařilo objevit železné ovčácké nůžky (obr. 8), pohřeb proto hodnotíme jako relativně starší. Mezi nejstarší hroby na lokalitě tak patří celá skupina hrobů ležící pod hrobem 65 . Se situací souvisí i hrob 78, zahloubený do starší části hřbitovní vrstvy. Podobnou situaci představuje skupina hrobů 47 až 50, které leží na zdivu

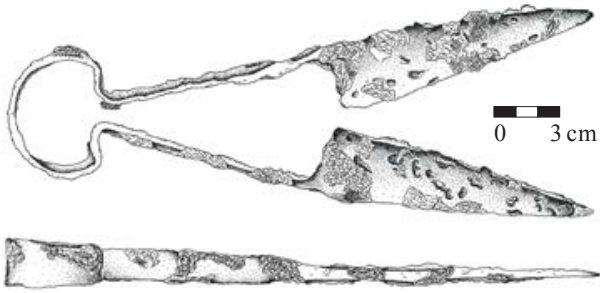

Obr. 8. Žabonosy, kostel sv. Václava. Hrob 65, ovčácké nůžky. Kresba V. Uramová.

Abb. 8. Žabonosy, St. Wenzelkirche. Grab 65, Schermesser. Zeichnung V. Uramová. předrománské př́ístavby jižní lodi bazilikálního kostela. Hroby vznikly po zániku bazilikální stavby, není však stanovena horní hranice možného datování - s románskou stavbou nutně nemusí souviset, proto tyto čtyři pohřby do seznamu nejstarších hrobů nezařazujeme.

Větší počet hrobů byl narušen gotickými zdmi. Hroby byly dotčeny zdivem gotické části lodi, stavbou sakristie, hrobky či předsíně. Jde tedy o hroby, které můžeme spojit s románskou, př́ípadně starší gotickou fází kostela. Zdmi gotického stáří bylo narušeno 13 hrobů $(H 4,7,10$, 16, 17, 20, 22, 33, 34, 35, 36, 37 a skrumáž kostí pod hrobem 34). Na základě pozorování stratigrafických vztahů, vyčlenění mladší a starší hřbitovní vrstvy, byly stanoveny další hroby patřící mezi nejstarší na lokalitě (H14, 15, 26, 29, 30, 67, 68, 77, 78, 86 a 91). Dva hroby (H14 a 26) byly překryty kamennými deskami.

Hroby neobsahovaly žádnou výbavu. Veškeré nálezy, které mohly původně být hrobovými prŕídavky, se nacházely v hřbitovní vrstvě (dvě záušnice, drobné kovové ozdoby gotického rázu, mince, kř́žky). Výjimku představuje již zmíněný hrob 65, ve kterém byly jako milodar uloženy ovčácké nůžky (obr. 8). Záušnice se našly ve starší hřbitovní vrstvě (uloženina 304, druhá ve výplni hrobové jámy hrobu 65). Při kostele se kontinuálně pohřbívá až do současnosti, nejmladší odkryté hroby jsou datovatelné do devatenáctého století (např. hrob 45 s ozdobami rakve z lakovaného papíru).

Předměty, byt' ojedinělé, a také hroby vyčleněné na základě vztahu k románským stavebním fázím kostela ukazují, že v Žabonosech vedle sebe existovala dvě současně používaná pohřebiště. Nálezy z pohřebiště, zkoumaného na konci 19. století (Píč 1893), je možno alespoň zčásti datovat do 12. století (záušnice s oběma konci s esovitou kličkou).

\section{Závěr}

Záchranný archeologický výzkum u kostela sv. Václava v Žabonosech je příkladem akce, při níž byl proveden výzkum zdánlivě neatraktivních archeologických terénů. Přinesl jednoznačné doklady složitého vývoje kostela v románském období a prokázal do té doby zpochybňovanou fázi předrománskou, a to dokonce v podobě trojlodní baziliky. Její přesné datování je úkolem pro další bádání, stejně jako určení stavebníka. Ukazuje se však, že možnosti obohacení fondu naší předrománské architektury je stále možné. 
Článek vznikl jako součást projektu 14-36938G „Středověká populace v centru a na venkově. Archeologie, bioarcheologie a genetika na pohřebištích Pražského hradu, středních a východních Čech“ podporovaného Grantovou agenturou ČR.

\section{Literatura}

BUDAVÁRY, V., 1939: Žabonosy, obec Plaňany, okr. Kolín. Výzkum 1938. Nálezová zpráva ulož. v archivu ARÚ AV ČR, Praha, v. v. i., č. j. 896/39.

- 1939a: Žabonosy. Nálezová zpráva ulož. v archivu ARÚ AV ČR, Praha, v. v. i., č. j. 897/39.

DVOŘÁK, F., 1936: Pravěk Kolínska a Kouřimska. Soupis archeologických památek. Kolín.

- 1937: Žabonosy, obec Plaňany, okr. Kolín. Nálezová zpráva ulož. v archivu ARÚ AV ČR, Praha, v. v. i., č. j. 2428/37.

FROLÍK, J., 2009: Zpráva o záchranném archeologickém výzkumu provedeném na lokalitě Žabonosy (okr. Kolín) - akce: Celková rekonstrukce a zpřístupnění kostela sv. Václava (smlouva 790089), ulož. v archivu ARÚ AV ČR, Praha, v. v. i., č. j. 11842/09.

- 2010: Zpráva o záchranném archeologickém výzkumu provedeném na lokalitě Žabonosy (okr. Kolín) - akce: Celková rekonstrukce a zpř́istupnění kostela sv. Václava (smlouva 790115), ulož. v archivu ARÚ AV ČR, Praha, v. v. i., č. j. 6930/10.

- 2010a: Záchranné archeologické výzkumy u kostelů v Tismicích a v Žabonosech (okr. Kolín) - Archäologische Rettungsgrabungen bei den Kirchen zu Tismice und Žabonosy (Bez. Kolín). In: Archeologické výzkumy v Čechách 2009. Sborník referátů z informačního kolokvia. Zprávy České archeologické společnosti - Supplément 78, 41-42. Praha.

KUDRNÁČ, J., 1963: Vývoj slovanského osídlení mezi pražským Povltavím, Labem, Sázavou a Výrovkou Die Entwicklung der slawischen Besiedlung zwischen dem Prager Moldaugebiet, der Elbe, Sázava und Výrovka, PA LIV, 173-223.

MERHAUTOVÁ, A., 1971: Raně stř̌edověká architektura v Čechách. Praha.

NZ Žabonosy 1950: Žabonosy, okr. Kolín. Nálezová zpráva ulož. v archivu ARÚ AV ČR, Praha, v. v. i., č. j. $757 / 50$.

- 1950a: Žabonosy, okr. Kolín. Nálezová zpráva ulož. v archivu ARÚ AV ČR, Praha, v. v. i., č. j. 868/50.

- 1950b: Žabonosy, okr. Kolín. Nálezová zpráva ulož. v archivu ARÚ AV ČR, Praha, v. v. i., č. j. 1841/50.

- 1950c: Žabonosy, okr. Kolín. Nálezová zpráva ulož. v archivu ARÚ AV ČR, Praha, v. v. i., č. j. 1963/50.

- 1950d: Žabonosy, okr. Kolín. Nálezová zpráva ulož. v archivu ARÚ AV ČR, Praha, v. v. i., č. j. $2369 / 50$.

- 1950e: Žabonosy, okr. Kolín. Nálezová zpráva ulož. v archivu ARÚ AV ČR, Praha, v. v. i., č. j. $3059 / 50$.

- 1950f: Žabonosy, okr. Kolín. Nálezová zpráva ulož. v archivu ARÚ AV ČR, Praha, v. v. i., č. j. $3299 / 50$.

- 1950g: Žabonosy, okr. Kolín. Nálezová zpráva ulož. v archivu ARÚ AV ČR, Praha, v. v. i., č. j. 3539/50.

PÍČ, J. L., 1893: Archaeologický výzkum ve středních Čechách, Památky archaeologické a místopisné XVI, 418-438.

- 1896: Hřbitov z první doby křest’anské v Žabonosech, PA XVI, 437-438.

- 1909: Starožitnosti země České III/1. Čechy za doby knížecí. Praha.

POCHE, E. a kol., 1982: Umělecké památky Čech 4 (T-Ž). Praha.

PRINC, M.-HEJNA, A.-RICHTER, M.-SMETÁNKA, Z., 1965: Žabonosy, okr. Kolín, poloha „U kostela“. Nálezová zpráva ulož. v archivu ARÚ AV ČR, Praha, v. v. i., č. j. 3659/65.

PROFOUS, A.-SVOBODA, J., 1957: Místní jména v Čechách. Jejich vznik, původní význam a změny. Díl IV (S-Ž). Praha.

SEDLÁČEK, A., 1998: Místopisný slovník historický království českého. Praha.

SEDLÁČEK, Z., 1994: Hlášení o archeologickém dozoru negativním. Žabonosy. Nálezová zpráva ulož. v archivu ARÚ AV ČR, Praha, v. v. i., č. j. 6728/94.

SEDLÁČEK, Z.-VENCL, S., 1974: Žabonosy, č. o. Plaňany, okr. Kolín. ZSO, opevněný kostel. Nálezová zpráva ulož. v archivu ARÚ AV ČR, Praha, v. v. i., č. j. 8105/74.

- 1975: Zpráva o leteckém snímkování na Kolínsku - Bericht über die Luftbildaufnahmen in der Gebiet von Kolín, AR XXVII, 151-158.

SOMMER, J., 1993: K románské podobě kostela v Žabonosech, ZPP 53, 233-234.

SOMMER, P.-VANĚK, V., 2007: Existe-t-il une architecture Slavníkienne. In: Slavníkovci v českých dějinách. Antiqua Cuthna 2, 20-34. Praha.

TŮMA, J., 1915: Kolínsko a Kouřimsko: obraz poměrů přírodních, života obyvatelstva i paměti časů minulých. Díl třetí. Paměti osad na Kouřimsku. Kolín.

TUREK, R., 1963: Čechy na úsvitě dějin. Praha. 
- 1982: Slavníkovci a jejich panství. Hradec Králové.

TVRDÍK, R., 2005: Žabonosy. Zpráva o archeologické akci. Nálezová zpráva ulož. v archivu ARÚ AV ČR, Praha, v. v. i., č. j. 3810/05.

- 2005a: Žabonosy. Zpráva o archeologické akci. Nálezová zpráva ulož. v archivu ARÚ AV ČR, Praha, v. v. i., č. j. 3811/05.

VARHANÍK, J., 1997: Ještě k románské podobě kostela v Žabonosech, ZPP 57, 265-266.

\section{Zusammenfassung}

\section{Die St. Wenzelkirche in Žabonosy (Bezirk Kolín) und ihre Anfänge}

Die St. Wenzelkirche in Žabonosy wird im Hinblick auf den 1937 im Südteil der Kirche gemachten Mauerwerksfund als vorromanisches Bauwerk angesehen. Aus diesem Grund wurde im Rahmen der Renovierung der verwüsteten Kirche eine archäologische Rettungsgrabung durchgeführt (Abb. 1). In der bisherigen Literatur wird die Entstehung der Kirche bereits für die Zeit Ende des 10. Jahrhunderts in Betracht gezogen (Abb. 2) und mit den Slavnikiden in Verbindung gebracht. An der Stelle der ursprünglichen Kirche errichtete man im 12. Jahrhundert eine neue Kirche, die im 14. Jahrhundert in gotischem Stil vergrößert wurde. Bereits ab dem 19. Jahrhundert steht Žabonosy unter archäologischer Beobachtung. Im Jahr 1893 wurde östlich der Kirche ein über 100 Gräber zählendes Gräberfeld ausgehoben, das in das 12. Jahrhundert datiert wird.

Durch die archäologische Rettungsgrabung wurde festgestellt, dass die Kirche an einer nicht besiedelten Stelle errichtet wurde. Zu dem ältesten Kirchenbau gehört tatsächlich eine bereits 1937 freigelegte Apsis. In der Apsis wurde der Rest eines Altarfundaments entdeckt. An die Apsis schloss das Längsschiff an, von dem uns Negativspuren von Abschnitten der Seitenmauern bekannt sind (Abb. 3:A). Der westliche Abschluss des Baus wurde nicht entdeckt. Die weitere Bauetappe bilden zwei Apsiden, die außen an der Nord- und Südseite des Schiffs freigelegt und unter Verwendung eines deutlichen Absatzes angeschlossen wurden. Das Aussehen der zweiten Bauetappe lässt sich als dreischiffige Basilika rekonstruieren (Abb. 3:B). Der entdeckte Bau wird von uns vorläufig in das ältere 12. bzw. in das 11. Jahrhundert datiert. Seine Funktion und Bedeutung für die lokale Besiedelung ist die Aufgabe einer weiteren Untersuchung. Im Verlauf des 12. oder im ersten Viertel des 13. Jahrhunderts wurde an der Stelle des älteren Bauwerks ein nach Osten hin verlagerter Neubau errichtet. Dabei handelte es sich um einen einschiffigen Bau mit nicht erhalten gebliebenem Abschluss an der Ostseite (Abb. 3:C). Die Kirche war durch ein Portal von der Südseite her zugänglich. In der weiteren Entwicklung wurde die Kirche mehrfach im romanischen Baustil umgestaltet. Sie wurde mit einer Tribüne ausgestattet, nachträglich wurde auch ein Turm angeschlossen (Abb. 3:D, 4). Das Erdgeschoss des Turms öffnete sich in die Umgebung ursprünglich durch eine Arkade (Abb. 3:E). Die gotische Bauetappe besteht aus einer Verlängerung des Kirchenschiffs nach Osten hin und aus der Errichtung eines neuen Chorraums. In der gleichen Bauetappe wurde auch eine Sakristei errichtet (Abb. 3:F). Mit den um das Jahr 1600 erfolgten Veränderungen hängt wahrscheinlich auch die Hinzufügung eines Vorraums vor dem Kircheneingang zusammen (Abb. 3:G).

Um die Kirche herum wurden intensiv Bestattungen durchgeführt. Durch die Störung der älteren Gräber wurden bis zu 2 m starke Friedhofsschichten gebildet, die Funde aus der Zeit zwischen dem 11. und 19. Jahrhundert enthielten. Insgesamt wurden 91 Gräber und deren Fragmente freigelegt (Abb. 5). Drei Gräber zählten nachweislich bereits zur vorromanischen Phase der Kirche (G31 [Abb. 6], G90 und der Überrest von Grabgrube 1903). Weitere 28 Gräber gehörten zum romanischen Bau. Eine kleine Gruppe von Gräbern hängen mit dem Mauerwerk des Nordschiffs des basilikalen Baus zusammen (G63 bis G66). Das jüngste Grab ist Grab Nr. 65 (Abb. 7), in ihm wurde ein Schermesser aus Eisen gefunden (Abb. 8). Zwei Gräber (G14 und G26) waren mit Steinplatten zugedeckt. 
Die archäologische Rettungsgrabung an der St. Wenzelkirche in Žabonosy lieferte Belege für die komplizierte Entwicklung der Kirche während der romanischen Epoche und erbrachte den Nachweis ihrer vorromanischen Phase, und zwar in Form einer dreischiffigen Basilika. Ihre genaue Datierung ist ebenso wie die Bestimmung des Bauherrn die Aufgabe weiterer Forschungen.

Der vorliegende Beitrag entstand im Rahmen des von der Förderagentur der Tschechischen Republik geförderten Projekts 14-36938G „Die Population des Mittelalters im Zentrum und auf dem Land. Archäologie, Bioarchäologie und Genetik auf den Gräberfeldern der Prager Burg und in Mittel- und Ostböhmen“.

PhDr. Jan Frolík, CSc., Archeologický ústav AV ČR, Praha, v. v. i., Letenská 4, 11801 Praha 1, Česká republika,frolik@arup.cas.cz

PhDr. Soňa Hendrychová, Archeologický ústav AV ČR, Praha, v. v. i., Letenská 4, 11801 Praha 1, Česká republika, hendrychova@arup.cas.cz 